\title{
OBSERVATIONS ON PYURIA IN CHILDREN
}

\author{
BY \\ J. M. STANSFELD and J. K. G. WEBB \\ From the Department of Child Health, Newcastle upon Tyne and Dryburn Hospital, Durham
}

(RECEIVED FOR PUBLICATION MAY 12, 1953)

The diagnosis of renal tract infection rests upon the recognition of symptoms and the demonstration of pyuria. The bacteriology of catheter specimens of urine can support this diagnosis but can never form its basis as contamination occurs so readily. In acute infections symptoms are usually prominent, but in chronic pyelonephritis, where the infection may be low grade but persistent, symptoms may be minimal. The diagnosis in such cases depends on the demonstration of pyuria which may be modest and intermittent. To know the difference between a high normal excretion of leucocytes in the urine and a low-grade but significant pyuria is therefore crucial.

It is our belief that the customary method of measuring pyuria by counts per high or low power microscope field is so crude that only gross amounts can be distinguished, and an undue reliance on the method will lead to many cases of renal tract infection being overlooked. There is, moreover, a lack of agreement in interpreting results when only a few cells are present. Campbell (1951) writes in his textbook that there is no accepted standard of what constitutes an abnormal amount of pus in the urine specimen as commonly examined. Considerable difficulty may arise in differentiating between a high normal exudate of leucocytes and mild pyuria.' He considers that in an uncentrifuged catheterized specimen 3 to 5 cells per low power field are within normal limits. Craig (1935) could not find more than 1 cell in 10 to 15 high power fields when examining urines of newborn infants. On the other hand, many authors believe that at least 6 to 8 cells per high power field should be present before the diagnosis of significant pyuria is justified. Much of the literature on the subject has been reviewed by Hepler and Scott (1935) who point out that various arbitrary limits of normal are given with no indication of the method of collection or examination, and that there is no report of a systematic study that would definitely confirm or refute many of the assumptions that appear in the literature on the subject.
An Addis count of pus cells in urine is more precise than the microscope field method. The range of such counts in normal children has been measured by Lyttle (1933) who made observations on 74 children aged between 4 and 12 years. Giles (1947), using the same technique with 20 normal children, obtained similar results (Table 1). The upper limit of normal may be taken as about $2 \mathrm{~m}$. epithelial and white blood cells in 12 hours or $4 \mathrm{~m}$. a day. Yet although the significance of results obtained by Addis counts on children can thus be judged fairly confidently, the method has the grave disadvantage that it is cumbersome to perform and so quite impracticable for everyday use.

TABLE 1

ADDIS COUNTS IN NORMAL CHILDREN

\begin{tabular}{l|l|l}
\hline Author & Range of White Blood Cells in 12 Hours & Average \\
\hline Lyttle & $9,000-2,822,000$ & 322,184 \\
Giles & $9,000-714,000$ & 329,500 \\
\hline
\end{tabular}

A third way of measuring pyuria is to count the number of cells in a known volume of urine. The technique, which was described by Block and Nyun (1916) and doubtless by others before, is easy to perform and, in our experience, quicker than microscope field counts. After the specimen has been well shaken, a drop is transferred to a Neubauer counting chamber and a count made of the number of cells in a cubic millimetre. Dukes (1928a and b), who examined in this way about a thousand uncentrifuged specimens of urine from normal men and women, concluded that under 10 cells per c.mm. was normal while over 100 cells was definitely pathological. He found counts usually over 500 per c.mm. in acute, and between 100 and 500 in chronic, renal infections.

During the last four years we have used the counting chamber method for measuring pyuria and we believe it to be the method of choice as it is accurate, simple to do, and the results are easily interpreted. We have found it to be invaluable in 
the detection of slight but significant pruria. Before considering the findings in renal tract infections the range of pus cell counts per cubic millimetre in the urines of normal children must first be known.

Pus Cell Counts (per c.mm.) in the Lrines of 632 Normal Children

We were interested primarily in urines naturally roided and uncentrifuged such as are routinely tested in the clinical sideroom. Furthermore we wished to know the significance of any pyuria in sick rather than healthy children. so specimens were collected from children who were in hospital but who did not

have any known or suspected renal tract disease. They were considered "normal' as regards the renal tract. A maximum of 10 specimens was obtained from each child and in most cases where a urine was found to contain more than 10 cells per c.mm. a catheter specimen was taken for examination and culture. Counts were made of the number of pus cells per cubic millimetre in each urine tested: epithelial or other cells were ignored.

The findings for boys are given in Table 2 and Fig. 1. One thousand one hundred and forty-two specimens were tested from 359 subjects. It will be seen that $98^{\circ}$ of the specimens contained 10 or fewer cells per c.mm.. and indeed the majority had either zero counts or but 1 per c.mm. The remaining $2{ }^{\circ}$. that is 21 specimens. had over 10 cells per c.mm. but only once were there more than 50 per c.mm. Allowing for the fact that more urines from infants than other age groups were tested. Table 2 shows that the results did not differ for various ages. It seems that urines from normal boys usually contain under 10 cells per c.mm.. and. in the absence of disease of the renal tract. it is rare to find over 50 cells per c.mm.

Table 3 and Fig. 2 show the results for girls. One thousand and sixty-seven specimens were tested from 273 subjects. As with bovs. most $\left(84^{\circ}{ }_{0} 1\right.$ specimens contained 10 or fewer cells per c.mm.. but higher counts were encountered more often in girls. Sixteen per cent. of the specimens had over 10 cells per c.mm.. While in $2^{\circ}$ o the counts exceeded 100 cells per c.mm. This increased incidence of higher counts did not apply to

FiG. 1.-Histogram of percentage irequency of urine fus zell counts per amm. in nurmal zoys.

TABLE 2

PLS CELL COLNTS IN LNSEDIMENTED. NATLRALLY VOIDED. LRINES FROM BOYS WITHOLT REIAL TRACT DISEASE

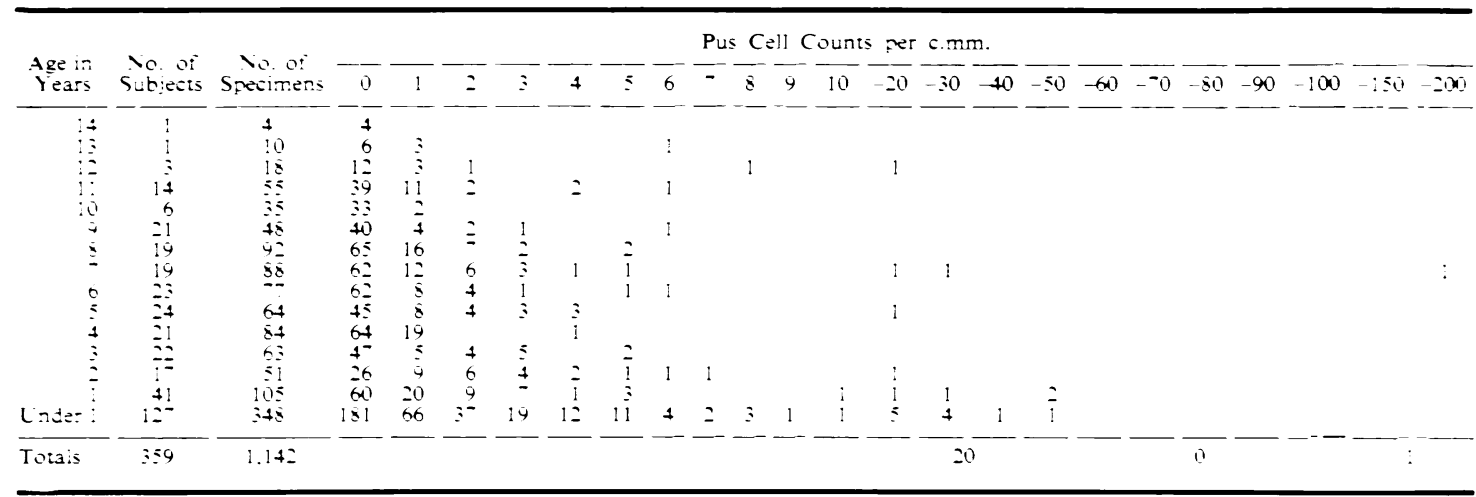


TABLE 3

PUS CELL COUNTS IN UNSEDIMENTED, NATURALLY VOIDED, URINES FROM GIRLS WITHOUT RENAL TRACT DISEASE

\begin{tabular}{|c|c|c|c|c|c|c|c|c|c|c|c|c|c|c|c|c|c|c|c|c|c|c|c|c|c|c|c|}
\hline & & & & & & & & & & & & & & Pus & Cell & Cour & nts pe & er c.r & $\mathrm{mm}$. & & & & & & & & \\
\hline in & $\begin{array}{l}\text { Sub- } \\
\text { jects }\end{array}$ & $\begin{array}{l}\text { Speci- } \\
\text { mens }\end{array}$ & 0 & 1 & 2 & 3 & 4 & 5 & 6 & 7 & 8 & 9 & 10 & -20 & -30 & -40 & -50 & -60 & -70 & -80 & -90 & -100 & -150 & -200 & -250 & -300 & -350 \\
\hline \multirow{11}{*}{$\begin{array}{r}13 \\
12 \\
11 \\
10 \\
9 \\
8 \\
7 \\
6 \\
5 \\
4 \\
3 \\
2 \\
1 \\
\text { Under } \\
1\end{array}$} & 2 & 20 & 4 & 3 & 2 & & 2 & 1 & & $\overline{1}$ & & & 2 & 3 & & & 1 & & & 1 & & & & & & & \\
\hline & 8 & 32 & 12 & 10 & 2 & & $\overline{2}$ & & & & 1 & & 1 & 1 & 2 & & & & & & & & 1 & & & & \\
\hline & $\begin{array}{r}5 \\
12\end{array}$ & $\begin{array}{l}12 \\
46\end{array}$ & $\begin{array}{r}2 \\
18\end{array}$ & $\begin{array}{l}2 \\
7\end{array}$ & $\begin{array}{l}2 \\
5\end{array}$ & $\begin{array}{l}2 \\
4\end{array}$ & 1 & 1 & 1 & & & 1 & 1 & $\begin{array}{l}1 \\
3\end{array}$ & 1 & 2 & & 1 & & & & & 1 & & 1 & & \\
\hline & 20 & 82 & 25 & 18 & 5 & 4 & 6 & 2 & 1 & 2 & 1 & & 4 & 10 & & & 2 & & 1 & & & 1 & & & & & \\
\hline & 17 & $\begin{array}{l}69 \\
40\end{array}$ & $\begin{array}{l}23 \\
16\end{array}$ & $\begin{array}{r}10 \\
8\end{array}$ & $\begin{array}{l}4 \\
2\end{array}$ & $\begin{array}{l}7 \\
2\end{array}$ & 5 & 2 & 1 & $\begin{array}{l}3 \\
2\end{array}$ & 2 & & 2 & $\begin{array}{l}4 \\
2\end{array}$ & $\frac{2}{2}$ & 1 & 1 & 1 & 1 & 1 & & 1 & 1 & & 1 & & \\
\hline & 22 & 143 & 56 & 14 & 9 & 8 & 5 & 2 & 2 & 6 & 1 & 3 & 2 & 8 & 8 & 6 & 2 & & 1 & 1 & & 3 & 4 & 1 & & 1 & \\
\hline & 15 & $\begin{array}{l}86 \\
82\end{array}$ & $\begin{array}{l}17 \\
28\end{array}$ & $\begin{array}{r}10 \\
8\end{array}$ & 99 & $\begin{array}{l}8 \\
3\end{array}$ & $\begin{array}{l}5 \\
3\end{array}$ & $\begin{array}{l}9 \\
3\end{array}$ & $\begin{array}{l}2 \\
2\end{array}$ & $\begin{array}{l}1 \\
1\end{array}$ & $\begin{array}{l}2 \\
3\end{array}$ & $2^{2}$ & $\begin{array}{l}4 \\
1\end{array}$ & $\begin{array}{l}2 \\
3\end{array}$ & $\begin{array}{l}3 \\
3\end{array}$ & $\begin{array}{l}3 \\
1\end{array}$ & $\begin{array}{l}3 \\
2\end{array}$ & $\begin{array}{l}2 \\
3\end{array}$ & 1 & & 2 & & 1 & 1 & 1 & 1 & 1 \\
\hline & 13 & 36 & 17 & & 1 & 2 & 1 & 2 & & & 2 & & 4 & 3 & 3 & & & & & & & & & 1 & & & \\
\hline & 27 & 92 & 42 & 8 & 5 & 7 & 6 & 5 & 4 & 5 & 2 & 1 & & 2 & $\begin{array}{l}4 \\
5\end{array}$ & $\frac{3}{2}$ & & 1 & & 3 & 1 & & & & 1 & - & - \\
\hline & & & & & & & & & & & & & & & & 2 & & 1 & & & 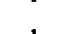 & & & & & & \\
\hline & 75 & 209 & 98 & 34 & 17 & 17 & 10 & 8 & 2 & 3 & 4 & 6 & & 3 & 5 & 1 & & & & & 1 & & & & & & \\
\hline Totals & 273 & 1,067 & & & & & & & & & & & & & 2 & 21 & & & & 2 & & & & & 20 & & \\
\hline
\end{tabular}

female infants, only $5 \%$ of whose specimens showed more than 10 cells per c.mm. and $0.5 \%$ more than 50 cells. We believe that baby girls have urine pus cell counts similar to those found in boys, while older girls may have higher counts although it is rare in the absence of renal tract disease to find over 500 cells per c.mm. and more than 100 per c.mm. should be regarded with suspicion.

We tried to find out a little about the circumstances under which occasional pus cells counts exceeding 10 per c.mm. occurred in children with normal renal tracts. Such counts tended to be repeated in successive specimens from the same child; thus the 21 examples in boys came from only 15 subjects and the 170 in girls from 84 subjects. In the case of boys there was usually fever at the time that the specimen with the higher count was passed, whereas with girls fever was as often absent as present. If a count exceeding 10 cells per c.mm. was found in the urine from a girl, we tried, when possible, to get her to void naturally another specimen and immediately afterwards a catheter was passed and the residual urine in the bladder drawn off. A comparison was then made of counts on the two specimens (Table 4). In some cases

TABLE 4

COMPARISON OF PYURIA IN SPECIMENS OF URINE AS PASSED WITH IMMEDIATELY FOLLOWING CATHETER SPECIMENS IN GIRLS

\begin{tabular}{|c|c|c|c|c|c|}
\hline \multicolumn{6}{|c|}{ Cell Counts per c.mm. in Urines } \\
\hline As Passed & Catheter & As Passed & Catheter & As Passed & Catheter \\
\hline $\begin{array}{l}0 \\
0 \\
0 \\
1 \\
2 \\
2 \\
3 \\
3 \\
3 \\
5 \\
7\end{array}$ & $\begin{array}{l}\mathbf{0} \\
0 \\
0 \\
0 \\
0 \\
0 \\
0 \\
5 \\
8 \\
0 \\
0\end{array}$ & $\begin{array}{l}10 \\
10 \\
12 \\
13 \\
16 \\
25 \\
27 \\
28 \\
49 \\
52 \\
58 \\
64\end{array}$ & $\begin{array}{r}0 \\
3 \\
2 \\
16 \\
4 \\
1 \\
3 \\
0 \\
0 \\
0 \\
0 \\
0\end{array}$ & $\begin{array}{r}68 \\
70 \\
98 \\
100 \\
132 \\
133 \\
160 \\
171 \\
223 \\
294 \\
306\end{array}$ & $\begin{array}{r}0 \\
1 \\
3 \\
1 \\
6 \\
2 \\
10 \\
0 \\
5 \\
2 \\
2\end{array}$ \\
\hline
\end{tabular}

neither specimen contained a significant number of cells, but in the majority a further high count was found in the naturally passed urine contrasting with few or no cells in the catheter specimen. Only once was a significantly higher count found in the resid u a 1 urine. I t thus appeared that in girls the $h$ i g h e r counts were most often due to con-

Pus cell counts per c.mm. tamination 
in the urethra or vulva. Similar comparisons have not been made with boys owing to the infrequency of their counts exceeding 10 cells per c.mm., but urethral contamination must be uncommon and we have only come across it once-in a boy with paraphimosis who had 390 cells per c.mm. in his urine.

Besides knowing the normal limits for pus cell counts in naturally voided urines it is important to know also the findings in catheter specimens in girls. We have therefore examined urines obtained by catheterization from 100 girls over a year old who did not have disease of the renal tract. The results are as expected; the highest count obtained was 41 cells per c.mm., the next 16 cells per c.mm. and the rest were all below 10 per c.mm., being usually 0 or 1 . It thus appears that pus cells counts in catheter specimens of urine from normal girls do not differ from those found in non-catheter specimens from boys or infants of either sex. If then, there is doubt about the significance of a count in a naturally voided urine from a girl over a year old, a catheter specimen may clarify whether or not the excess of cells is due to contamination, especially if it can be shown that at the time the catheter is passed abnormal numbers of cells are still present in an ordinary specimen.

\section{Correlation of Estimates of Pyuria by Cubic Milli- metre Counts with those of Other Methods}

Our findings of pus cell counts per c.mm. in normal children agree closely with those found by Dukes (1928a and b) in adults. Some further evidence for the validity of the observations may be deduced from Addis counts. If the few epithelial cells that may be found are disregarded and the Addis count assumed to be only of pus cells, then for a maximum normal excretion of 4 million leucocytes a day the cell count per cubic millimetre can be calculated for various daily outputs (Table 5). The figures agree with those actually found.

\section{TABLE 5}

CALCULATED COUNTS FOR A MAXIMUM NORMAL ADDIS COUNT OF 4 MILLION LEUCOCYTES A DAY

\begin{tabular}{|c|c|}
\hline Daily Urine Volume & Count (per c.mm.) \\
\hline $\begin{array}{r}400 \mathrm{ml} . \\
600 \mathrm{ml} . \\
800 \mathrm{ml} . \\
1,000 \mathrm{ml} .\end{array}$ & $\begin{array}{r}10 \cdot 0 \\
6.6 \\
5.0 \\
4 \cdot 0\end{array}$ \\
\hline
\end{tabular}

An attempt was also made to correlate the counts in c.mm. with those found per high power microscopic field, and in $\mathbf{5 0}$ specimens counts were made by the two methods. There were considerable difficulties owing to the inaccuracies of the microscope field counts. These varied widely with the thickness of the drop held by the coverslip, and when only a few cells were present it was difficult to avoid overlapping fields. However, Table 6 shows that an average of one cell in each high power field of uncentrifuged urine is very approximately equivalent to some 250 to 500 cells per c.mm. We are led to the striking conclusion that, except in girls over a year old, an average count of more than one cell in 10 high power fields seldom occurs under normal conditions.

TABLE 6

COMPARISON OF COUNTS PER CUBIC MILLIMETRE AND PER HIGH POWER FIELD

\begin{tabular}{|c|c|c|c|}
\hline Number Tested & Cells per c.mm. & $\begin{array}{l}\text { Cells in } 50 \text { High } \\
\text { Power Fields }\end{array}$ & $\begin{array}{c}\text { Average per } \\
\text { High Power } \\
\text { Field }\end{array}$ \\
\hline $\begin{array}{r}8 \\
10 \\
4 \\
8 \\
6 \\
7 \\
7\end{array}$ & $\begin{array}{r}2,000-5,000 \\
1,000-2,000 \\
500-1,000 \\
200-500 \\
100-200 \\
50- \\
0-\quad 50\end{array}$ & $\begin{array}{rr}70-1,166 \\
29- & 818 \\
55- & 99 \\
6- & 216 \\
2- & 18 \\
1- & 10 \\
1- & 12\end{array}$ & $\begin{array}{r}1-23 \\
<1-16 \\
1-2 \\
<1-4 \\
<1 \\
<1 \\
<1\end{array}$ \\
\hline
\end{tabular}

Urine Pus Cell Counts per Cubic Millimetre in Pathological Conditions of the Renal Tract

Having considered the limits of excretion of leucocytes under normal conditions, we turn now to some aspects of our findings in pathological conditions. In acute pyelonephritis symptoms are usually striking, and the diagnosis is readily confirmed by a gross pyuria. It is in chronic pyelonephritis, when symptoms may be slight and apparently unrelated to the renal tract, that the recognition of less obvious pyuria is so important. We have studied 41 infants with chronic pyelonephritis. In all cases symptoms had been present for three weeks or more, and the diagnosis was based on a consistent clinical picture with no other demonstrable disease, pyuria and, in most cases, positive urine cultures.

There are two points emerging from this study which we wish to emphasize. The first is that in many of these cases pyuria was slight. Table 7 shows the maximum count found in each case. If such counts had been found by the microscopic

TABLE 7

MAXIMUM PYURIA FOUND IN 41 INFANTS WITH CHRONIC RENAL TRACT INFECTION

$\begin{aligned} & \text { Pus cells } \\ & \text { per c.mm. }\end{aligned}$
$\begin{aligned} & \text { Number } \\ & \text { of cases }\end{aligned}$




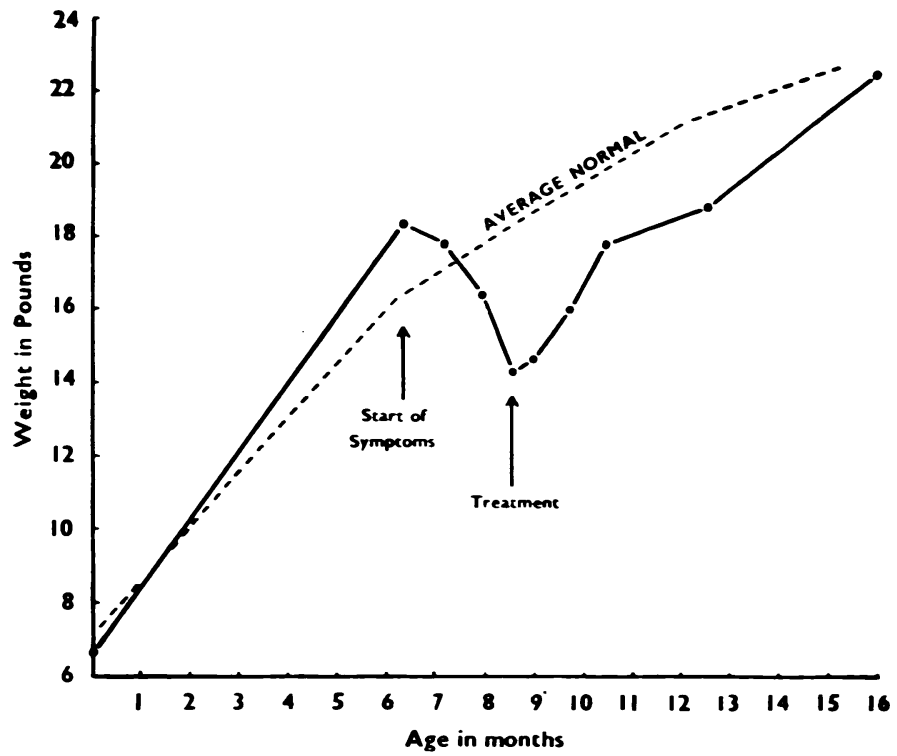

FKG. 3.-Weight chart of case of chronic pyelonephritis with slight pyuria, showing response to treatment.

field method, and 1 or 2 cells per high power field accepted as normal, then the majority and certainly those with less than 1,000 cells per c.mm. would not have been recognized at all. Even if an average of 1 cell in 10 high power fields was accepted as the upper limit of normal then, owing to the uncertainties of the method, many would still have been missed. No other method than the one employed could have revealed the significance of the pyuria in the two cases where the highest count was between 50 and 100 cells per c.mm.

The second point is that pyuria was not constant, the cell count varying widely in successive specimens. This is not a new observation. Geisinger (1931) drew attention to the intermittency of pyuria in pyelonephritis even when the infection was acute. It is important to allow for this intermittency if the mistake of ruling out a renal tract infection on the strength of one or even several normal urines is to be avoided. In our cases, although significant

TABLE 8

FIRST SPECIMEN OF URINE TESTED CONTAINING SIGNIFICANT PYURIA IN 41 INFANTS WITH CHRONIC

\begin{tabular}{l|c|c|c|c|c|c|c|c}
\hline & \multicolumn{7}{|c|}{ Specimen Tested } \\
\hline & 1st & 2nd & 3rd & 4th & 5th & 6th & 7th & 11th \\
$\begin{array}{l}\text { Cases with no pre- } \\
\text { vious therapy }\end{array}$ & 15 & 10 & 1 & 1 & 1 & 3 & 1 & 1 \\
\hline $\begin{array}{l}\text { Cases with pre- } \\
\text { vious therapy }\end{array}$ & 5 & 0 & 1 & 1 & 1 & & \\
\hline
\end{tabular}

pyuria was found in most instances in one of the first two specimens examined, this was by no means always so as Table 8 shows. In the most striking case in the series, an infant with a very suggestive history and no previous treatment, 10 specimens were examined without an excess of cells being found and the eleventh specimen contained only 63 cells per c.mm. Yet a later specimen contained over 1,200 cells per c.mm. and so the diagnosis was confirmed beyond all doubt. In practice it follows that whenever pyelonephritis is suspected on clinical grounds, specimens of urine must be examined repeatedly. We cannot state how many negative examinations are needed to exclude infection confidently: this is bound to depend upon the circumstances.

Significant pyuria is not confined to renal tract infections although its demonstration is necessary for their diagnosis. It may also be found in other circumstances and was, for instance, consistently present in 22 infants with hyperchloraemic renal acidosis whom we studied (Table 9). The maximum

TABLE 9

MAXIMUM PYURIA FOUND IN 22 INFANTS WITH IDIOPATHIC RENAL ACIDOSIS

$\begin{aligned} & \text { Pus celks } \\ & \text { per c.mm. }\end{aligned}$
$\begin{aligned} & \text { Number } \\ & \text { of cases }\end{aligned}$$\frac{50-100}{2} \frac{-200}{4} \frac{-300}{5} \frac{-500}{6} \frac{-1,000}{3} \frac{-2,000}{-\frac{-5,000}{2}}$

counts were similar to those found in chronic pyelonephritis but on an average lower. As renal acidosis may be clinically indistinguishable from chronic pyelonephritis the diagnosis depends on the appropriate biochemical investigations which need to be made in all cases with pyuria.

\section{Conclusion}

In this paper we have made a plea for the consistent use of more accurate criteria in the investigation of possible chronic renal tract infections. We believe that with the data we have provided it is possible, in most cases, to make a confident diagnosis of pyelonephritis. Nevertheless, as there can be no critical figure for pus cell counts in urine, above which there is infection and below which there is not, one is bound occasionally to encounter difficult 
border-line cases. The most frequent problem is that of a baby with a clinical picture suggestive of pyelonephritis but without significant pyuria. If 10 urines from such a case are completely free of pus, in spite of continuing symptoms, we reconsider the diagnosis. But if there are several counts of 10 to 20 cells per c.mm. we examine further specimens, if necessary over a long period. If the clinical picture is really suggestive of pyelonephritis, we have accepted one count above 100 cells per c.mm. as confirming the diagnosis, at any rate sufficiently to warrant a therapeutic trial. The following case helps to illustrate this.

A baby girl aged 9 months had a 10-week history of symptoms very suggestive of chronic pyelonephritis.

Apart from slight wasting there were no abnormal physical signs, and the blood chloride and alkali reserves were normal. The first four urine specimens examined contained $0,3,0$ and 113 pus cells per c.mm. Although a catheter specimen of urine after this contained only 4 cells per c.mm. and was sterile, she was given a routine course of sulphadimidine. She improved rapidly, becoming free of symptoms within a week, and there was no relapse during nine months' follow-up. Fig. 3 shows her weight graph.
In this case the evidence of pyelonephritis was slender, but the response to treatment provides a further basis for the diagnosis, and surely justifies the adoption of this policy in similar cases.

Since this paper was written we have seen the article by $\mathbf{P}$. L. Masters on 'Urinary Changes in Infections of the Urinary Tract in Childhood', which appeared in the Guy's Hospital Reports, vol. 102, No. 1, 1953. It is interesting to note the similarity of the conclusions reached in these two independent investigations.

We are extremely grateful to Professor Sir James Spence and Dr. V. Smallpeice for permission to use their cases and for encouragement and help at different stages of this work. We are also greatly indebted to Dr. R. G. Macfarlane whose introduction of an exact estimation of pus in urine as a routine procedure at Oxford first drew our attention to the value of the method.

\section{REFERENCES}

Block, E. B. and Nyun, K. (1916). Sth. med. J., Bgham. Ala., 9, 972. Campbell, M. (1951). Clinical Pediatric Urology. Philadelphia. Craig, W. S. (1935). Archives of Disease in Childhood, 10, 337. Dukes, C. (1928a). Proc. roy. Soc. Med., 21, 1179. - (1928b). Brit. med. J., 1, 391.

Geisinger, J. F. (1931). J. Urol., Baltimore, 25, 649.

Giles, M. D. (1947). Archives of Disease in Childhood, 22, 232. Hepler, A. B. and Scott, R. T. (1935). J. Amer. med. Ass., 105, 499. Lyttle, J. D. (1933). J. clin. Invest., 12, 87. 